\title{
The Impact of Routine Transvaginal Ultrasound Measurement of the Cervical Length on the Prediction of Preterm Birth: A Retrospective Study in a Tertiary Hospital
}

\section{O impacto da medição por rotina do comprimento cervical por ecografia transvaginal na predição de parto pré-termo: Um estudo retrospetivo num hospital terciário}

\author{
Joana Patricia Rodrigues Félix Peixoto de Almeida1잉 \\ Alexandra Matias Pereira Cunha Coelho Macedo ${ }^{3 \odot}$

\footnotetext{
${ }^{1}$ Department of Gynecology and Obstetrics, Faculdade de Medicina, Hospital Pedro Hispano, Universidade do Porto, Porto, Portugal

${ }^{2}$ Department of Pathology, Instituto Português de Oncologia do Porto, Porto, Portugal Hospitalar Universitário São, Universidade do Porto, Porto, Portugal
} \\ 3 Department of Gynecology and Obstetrics, Faculdade de Medicina, Centro
}

Carla Maria Magno Bartosch ${ }^{2}$

Address for correspondence Joana Patricia Rodrigues Félix Peixoto de Almeida, PhD, R. de Dr. Eduardo Torres, Sra. da Hora, Portugal (e-mail: joanapatriciafelix@gmail.com).

Rev Bras Ginecol Obstet 2021;43(4):264-274.

received

January 17, 2020

accepted

December 16, 2020
Preterm birth (PTB) is a major obstetric problem associated with high rates of neonatal morbidity and mortality. The prevalence of PTB has not changed in the last decade; thus, the establishment of a screening test and effective treatment are warranted. Transvaginal ultrasound measurement of the cervical length (TUCL) has been proposed as an effective method to screen pregnant women at a higher risk of experiencing PTB. Objective To evaluate the applicability and usefulness of second-trimester TUCL to predict PTB in a cohort of Portuguese pregnant women.

Methods Retrospective cross-sectional cohort study including all singleton pregnant women who performed their second-trimester ultrasound (between weeks 18 and $22+6$ days) from January 2013 to October 2017 at Centro Hospitalar Universitário São João.

Results Our cohort included 4,481 women. The prevalence of spontaneous PTB was of $4.0 \%$, with $0.7 \%$ occurring before the 34 th week of gestation. The mean TUCL was of $33.8 \mathrm{~mm}$, and percentiles 3, 5 and 10 corresponded to TUCLs of $25.0 \mathrm{~mm}, 27.0 \mathrm{~mm}$ and $29.0 \mathrm{~mm}$ respectively. The multiple logistic regression analysis, including maternal age, previous PTB and cervical surgery showed a significant negative association between TUCL and PTB, with an odds ratio (OR) of 0.92 (95\% confidence interval [95\%Cl]: $0.90-0.95 ; p<0.001)$. The use of a TUCL of $20 \mathrm{~mm}$ is the best cut-off, when compared with the 25-mm cut-off, improving the prediction of risk.

- cervical length cut-off

DOI https://doi.org/ 10.1055/s-0041-1726053. ISSN 0100-7203. (c) 2021. Federação Brasileira de Ginecologia e Obstetrícia. All rights reserved.

This is an open access article published by Thieme under the terms of the Creative Commons Attribution License, permitting unrestricted use, distribution, and reproduction so long as the original work is properly cited. (https://creativecommons.org/licenses/by/4.0/)

Thieme Revinter Publicações Ltda., Rua do Matoso 170, Rio de Janeiro, RJ, CEP 20270-135, Brazil 


\section{Resumo}

\section{Palavras-chave}

- parto pré-termo

- rastreio parto prétermo

- comprimento cervical por ecografia transvaginal

- valor de referência do comprimento cervical
Conclusion The present study showed an inverse association between TUCL and PTB, and that the inclusion of other risk factors like maternal age, previous PTB and cervical surgery can improve the screening algorithm. Furthermore, it emphasizes that the TUCL cut-off that defines short cervix can differ according to the population.

O parto pré-termo (PPT) é uma grande complicação obstétrica que se associa a elevadas taxas de morbimortalidade neonatal. A sua prevalência não tem alterado na última década, sendo esencial determinar uma forma de rastreio e tratamento eficaz. A medição ecográfica transvaginal do comprimento cervical tem sido proposta como um método eficaz de rastreio das grávidas com risco aumentado de PPT.

Objetivo Avaliar a aplicabilidade e utilidade da medição ecográfica transvaginal do comprimento cervical na previsão de PPT numa amostra de grávidas portuguesas.

Método Estudo de coorte retrospectivo incluindo todas as grávidas com gestação unifetal que realizaram ecografia do $2^{\circ}$ trimestre (de 18 a 22 semanas +6 dias) no Centro Hospitalar Universitário de São João entre janeiro de 2013 e outubro de 2017. Resultados A nossa amostra incluiu 4.481 mulheres. A prevalência de PPT espontâneo foi de $4,0 \%$, sendo que $0,7 \%$ ocorreu antes das 34 semanas de gestação. A média do comprimento cervical por ecografia transvaginal foi $33,8 \mathrm{~mm}$, e os percentis 3,5 e 10 da amostra corresponderam a comprimentos cervicais de $25,0 \mathrm{~mm}, 27,0 \mathrm{~mm}$ e $29,0 \mathrm{~mm}$, respetivamente. A regressão logística múltipla, que incluiu a idade materna, PPT anterior e antecedentes de conização, demonstrou uma associação estatisticamente significativa entre o comprimento cervical e o risco de PPT, com um risco relativo de 0,92 (intervalo de confiança de 95\% [IC95\%]: 0.90-0.95; $p<0.001$ ). A utilização de um valor de referência de comprimento cervical de $20 \mathrm{~mm}$, quando comparado com o valor de referência de $25 \mathrm{~mm}$, melhora a previsão do risco de PPT. Conclusão Este estudo demostra uma associação entre o comprimento cervical avaliado por ecografia tranasvaginal e o risco de PPT, e salienta que a inclusão de outros fatores de risco, como idade materna, PPT anterior e antecedentes de conização podem melhorar o algoritmo de rastreio. Realça ainda que o valor de comprimento cervical utilizado para definir "colo curto" varia de acordo com a população em estudo.

\section{Introduction}

The World Health Organization (WHO) defines preterm birth (PTB) as a delivery that occurs before the 37th week of gestation. It can occur spontaneously or due to medical induction (iatrogenic). Poorly understood to date, spontaneous PTB is a heterogeneous syndrome with multiple underlying pathophysiologic events and causes,.

Approximately $11 \%$ of infants worldwide are born too soon, corresponding to 15 million premature newborns every year. ${ }^{1-3}$ The prevalence ranges from $5 \%$ in European developed countries to $18 \%$ in certain African countries, but these international differences may reflect variations in definitions rather than a true epidemiological difference. For example, the method to determine the gestational age and different viability limits can influence this rate. In Portugal, the prevalence of singleton live preterm newborns is of $7.4 \%{ }^{4}$

Despite all advances in medicine, PTB is still an important health problem, and the leading cause of neonatal mortality. Prematurity is associated with multiple neonatal complications and long-term morbidity. ${ }^{5,6}$
Fetal development is a continuum, and the risk of perinatal complications is inversely related to the gestational age at delivery. For this reason, some experts recommend a subclassification of PTB into early PTB ( $<34$ weeks) and late PTB (between 34 weeks and 36 weeks +6 days), as the negative impact is different in the two groups. ${ }^{7}$ Infants born before the 32 th week of gestation represent less than $2 \%$ of all premature births, but they contribute to $50 \%$ of the overall perinatal mortality. ${ }^{8}$

Preterm birth is such a major economic and social burden that its reduction is one of the Millennium Development Goals established by the United Nations. ${ }^{9}$ Unfortunately, despite all efforts, the rate of prematurity has not changed in the past 30 years, and, in 2016, the WHO included PTB as one of the top-10 priority research areas. ${ }^{10,11}$

During the last years, many risk scores have been proposed to predict PTB, but they all have a low sensitivity and poor positive predictive value (PPV). ${ }^{12,13}$ The history of previous spontaneous PTB, for example, is the most significant risk factor known, but only $10 \%$ to $15 \%$ of PTBs occur after a previous event. ${ }^{14,15}$ 


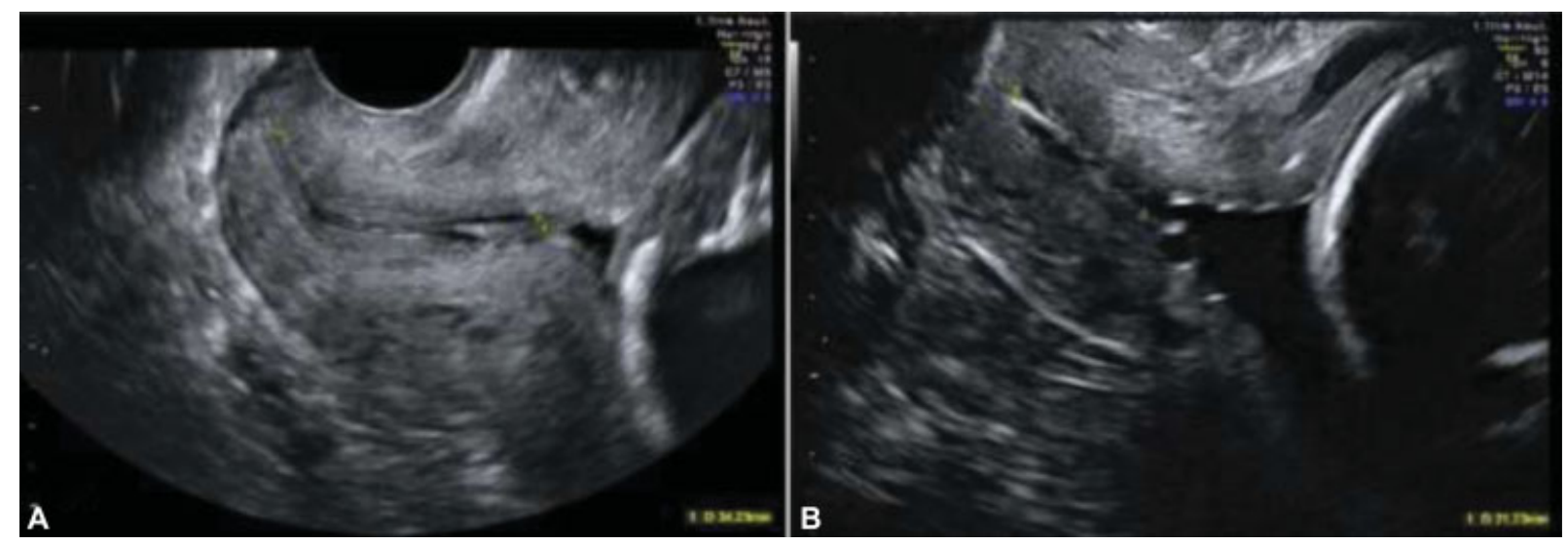

Fig. 1 Transvaginal ultrasound measurement of the cervical length (TUCL). (A) Normal cervix; (B) short cervix.

As the majority of spontaneous PTBs occur in low-risk pregnancies, Andersen et al. ${ }^{16}$ (1990) proposed the use of transvaginal ultrasound measurement of the cervical length (TUCL) as a predictor of PTB. Since then, the technique has been well standardized, and its reproducibility, confirmed. ${ }^{17,18}$

The risk of experiencing PTB is inversely correlated to the cervical length, but the ideal cut-off for clinical use is still controversial. ${ }^{16,19-23}$ By definition, a cervical length below the 10 th centile for gestational age is considered "short." This value varies according to the gestational age, the populational distribution of TUCL, and the prevalence of PTB. In the initial trials, the 10th centile was of $25 \mathrm{~mm}$; therefore, this cut-off has been widely used. ${ }^{15,24-27}$ Since then, many cutoffs (from $15 \mathrm{~mm}$ to $30 \mathrm{~mm}$ ) have been proposed, but none is consensual.

The main objective of the present study was to evaluate the applicability and usefulness of second-trimester TUCL to predict PTB in Portuguese pregnant women. We analyzed the distribution of TUCL in our cohort and determined the prevalence of short cervix using different cut-offs. Furthermore, we developed models to estimate the best TUCL cut-off in our cohort and improve its usefulness.

\section{Methods}

The present was an observational, retrospective cross-sectional cohort study carried out at the Obstetrics and Gynecology Department of Centro Hospitalar Universitário São João (CHUSJ), Portugal, after approval by the hospital's ethics committee (CES 81-17).

We included all singleton pregnant women who underwent the second-trimester ultrasound (the 18th week to the 22nd week +6 days, determined by the crown-rump length before the 14th week) from January 2013 to October 2017 in this hospital. Delivery in the same institution and the existence of delivery data were also inclusion criteria. We excluded all women that had induced PTBs for medical reasons (including premature rupture of membranes), cervical cerclage performed prior to screening, diagnosis of chorioamnionitis, and deliveries before the 24th week.
The ultrasound exams at CHSJ are performed by obstetricians with accreditation from the Fetal Medicine Foundation (FMF) for cervical assessment. However, because the universal screening of TUCL is not mandatory, all ultrasound images available through the Astraia software (Astraia Software, $\mathrm{GmbH}$, Munich, Germany) were reviewed in order to identify patients with an ultrasound image that complied with standard the rules of the FMF, which recommends the use of a transvaginal probe with the identification of the sagittal view of the cervix, occupying $75 \%$ of the image. Identification of the internal os, external os and cervical canal is essential. The measurement is performed in a straight line between the external and internal os. Care should be taken to distinguish between the cervical canal and the lower uterine segment (-Fig. 1).

At our hospital, all pregnant women with TUCLs $\leq 25 \mathrm{~mm}$ are considered to have a short cervix, and vaginal progesterone or the Arabin (Dr. Arabin GmbH \& Co., Witten, Germany) pessary is suggested.

Maternal characteristics, medical history, obstetric history and delivery data were obtained from the database of the Obstetrics and Gynecology Department through the Obscare software. This data was compiled using the Statistical Package for the Social Sciences (SPSS, IBM Corp., Armonk, NY, US) software, version 24 , for the statistical analyses. The continuous variables were expressed as means \pm standard deviations (SDs), and frequencies and percentages were used to describe the categorical variables.

The frequencies of PTB were calculated according to different groups of cervical length measurements. The diagnostic ability of different TUCL cut-offs was evaluated in terms of sensitivity, specificity, PPV, negative predictive value (NPV), and the area under the curve (AUC).

An exploratory univariate analysis of clinical and demographic global data was first performed to determine the variables that predicted PTB and those associated with TUCL. All of the hypothesis tests conducted were two-tailed, and they included the Student $t$-test, the Chi-squared $\left(X^{2}\right)$ test, and the Fisher exact test, as appropriate. Then, we developed a multivariate logistic regression model aiming to predict 
PTB as the outcome, using the TUCL as the explanatory variable, and including the main effects of maternal age, previous PTB and cervical surgery. For all of these analyses, values of $p<0.05$ were considered statistically significant.

To select an optimal TUCL cut-off, we used the maximum likelihood and a confidence interval based on a likelihood ratio test. The likelihoods were calculated for a series of our multivariate logistic regression model using all TUCL cuto-ffs between $8 \mathrm{~mm}$ and $50 \mathrm{~mm}$. The $95 \%$ lower and upper confidence bounds were determined as parameter values that reduce the maximum likelihood by $\mathrm{X}^{2}(0.05,1) / 2=1.92$. Using this optimal TUCL cut-off, we then assessed the potential differential effects across subgroups of risk factors using a stratified analysis. The effect modification among strata was checked using a test of homogeneity. Adjusted estimates were calculated using the Cochran-Mantel-Haenszel method.

In Portugal, the most used cut-off is TUCL $\leq 25 \mathrm{~mm}$. In order to compare our optimal cut-off with the 25 -mm cutoff, we classified each woman into groups of predicted probabilities derived from corresponding multivariate models using each cut-off. We then cross-classified these groups and compared them to the observed proportions of events in each group.

\section{Results}

During the aforementioned period, 8,016 women underwent a routine second-trimester ultrasound and delivery at CHUSJ. In total, 3,476 women were excluded from this group for the following reasons: delivery before the 24 th week $(n=5)$,; medically-induced PTB $(\mathrm{n}=241)$; cervical cerclage prior to ultrasound ( $n=19)$; diagnosis of chorioamnionitiss $(n=3)$; absence of cervical length measurement $(n=958)$; and images of the cervical length measurement that did not comply with FMF recommendations $(n=2,426)$. Within the latter group, the major reason for exclusion was a transabdominal measurement $(n=1,275)$, instead of the transvaginal approach preconized by the FMF. Some women presented more than one exclusion criteria.

Our final cohort consisted of 4,481 women with a mean age of $30.7 \pm 5.5$ years. Primigravidae represented $45.4 \%$ of the sample, and $56.2 \%$ had no previous delivery. Most of them had no medical $(86.5 \%)$ or obstetric $(96.7 \%)$ relevant background. Only $1.6 \%$ of these women had a previous spontaneous PTB, and $0.9 \%$ had history of cervical surgery, the 2 major known risk factors for PTB.

Spontaneous delivery occurred in $64.3 \%$ of the cases, and $76.4 \%$ of the women underwent vaginal delivery. The prevalence of spontaneous PTB prevalence of the original cohort $(8,016$ women) was of $6.9 \%$ (553), and, after applying the exclusion criteria (with the sample reduced to 4,481 women) the prevalence dropped to $4.0 \%(n=179)$, mainly due to the exclusion of medically-induced PTB. In total, 96.0\% $(n=149)$ of the cases of PTB occurred between the 34th and 37th weeks, and $0.7 \%(n=30)$ occurred before 34th week of gestation. The maternal and clinical characteristics of our cohort are described in table 1.

The mean gestational age at the time of the ultrasound was 21 weeks +3 days, with a distribution of $0.2 \%$ (8) at 18 weeks, $0.5 \%(22)$ at 19 weeks, $12.4 \%(555)$ at 20 weeks,

Table 1 Maternal and clinical characteristics of the study population

\begin{tabular}{|c|c|c|}
\hline Maternal features & Medical background & Risk factors for Preterm birth \\
\hline $\begin{array}{l}\text { Age (years) } \\
\text { Mean } \pm \text { standard deviation: } 30.7 \pm 5.5 \\
\text { Min: } 14 \\
\quad \text { Max: } 50 \\
\text { Body mass index }\left(\mathrm{kg} / \mathrm{m}^{2}\right) \\
\text { Mean } \pm \text { standard deviation: } 24.6 \pm 4.9 \\
\text { Obesity }(>30): 8.0 \% \\
\text { Years of schooling } \\
<4 \text { th grade: } 0.7 \% \\
\text { 4th to } 12^{\text {th }} \text { grades: } 64.6 \% \\
>12^{\text {th }} \text { grade: } 34.7 \% \\
\text { Smokers: } 12.9 \% \\
\text { Alcohol/drug users: } 0.2 \%\end{array}$ & $\begin{array}{l}\text { None: } 86.5 \% \\
\text { Uterine malformations: } 0.3 \% \\
\text { Psychiatric disorders: } 1.4 \% \\
\text { Sexually-transmitted diseases: } 1.0 \% \\
\text { Cardiac or renal disorders: } 1.0 \% \\
\text { Diabetes: } 0.7 \% \\
\text { Hypertension: } 2.6 \% \\
\text { Hypothyroidism: } 5.2 \% \\
\text { Neoplasia: } 0.8 \%\end{array}$ & $\begin{array}{l}\text { Spontaneous preterm birth: } 1.6 \% \\
\text { Cervical surgery: } 0.9 \% \\
\text { Short cervical length ( } \leq 25 \mathrm{~mm}) \\
\text {-» On } 2^{\text {nd }} \text {-trismester ultrasound: } 3.0 \% \\
\text { Obstetric background } \\
\text { None: } 96.7 \% \\
\text { Preeclampsia: } 0.9 \% \\
\text { Fetal death: } 0.6 \% \\
\text { Fetal malformation: } 0.4 \% \\
2^{\text {nd }} \text { T abortion: } 0.1 \%\end{array}$ \\
\hline Obstetric intercurrences & Actual obstetric data & Time of delivery \\
\hline Fetal growth restriction: $3.9 \%$ & Primigravida: $45.4 \%$ & Mean: 39.2 weeks \\
\hline Fetal malformation: $1.6 \%$ & Nullipara: $56.2 \%$ & Minimum: 24.2 weeks \\
\hline Urinary infection: $3.2 \%$ & Assisted reproduction: $2.7 \%$ & Maximum: 42 weeks \\
\hline Other infections: $4.4 \%$ & Labor induction: $35.7 \%$ & Term delivery ( $\geq 37$ week): $96.0 \%$ \\
\hline Hypertensive syndrome: $3.2 \%$ & Vaginal delivery: $76.4 \%$ & Preterm delivery (< 37 week): $4.0 \%$ \\
\hline Gestational diabetes: $9.6 \%$ & Male newborn: 50.6\% & Early preterm birth ( $<34^{\text {th }}$ week): $0.7 \%$ \\
\hline Surgery on $1^{\text {st }} / 2^{\text {nd }}$ trimesters: $0.2 \%$ & & Late preterm birth ( $\geq 34^{\text {th }}$ week): $3.3 \%$ \\
\hline
\end{tabular}


Table 2 Distribution of preterm and term births across different cervical length intervals

\begin{tabular}{lllll}
\hline Cervical length & $\begin{array}{l}\text { Early preterm birth } \\
(<34 \text { weeks): } \mathbf{n}(\%)\end{array}$ & $\begin{array}{l}\text { Preterm birth } \\
(<37 \text { weeks): } \mathbf{n}(\%)\end{array}$ & $\begin{array}{l}\text { Term birth } \\
(\geq 37 \text { weeks): } \mathbf{n}(\%)\end{array}$ & Total: $\mathbf{n}(\%)$ \\
\hline$<15 \mathrm{~mm}$ & $4(13.3)$ & $5(2.8)$ & $11(0.3)$ & $16(0.4)$ \\
15.1 to $20 \mathrm{~mm}$ & $3(10.0)$ & $4(2.2)$ & $11(0.3)$ & $15(0.3)$ \\
20.1 to $25 \mathrm{~mm}$ & $0(0)$ & $6(3.4)$ & $74(1.7)$ & $80(1.8)$ \\
25.1 to $30 \mathrm{~mm}$ & $3(10.0)$ & $30(16.8)$ & $506(11.8)$ & $536(12.0)$ \\
$\geq 30 \mathrm{~mm}$ & $20(66.7)$ & $134(74.9)$ & $3,700(96.5)$ & $3,834(85.6)$ \\
\hline
\end{tabular}

Table 3 Sensitivity and specificity of the cervical length measurement to predict preterm birth and cumulative incidence of the different cut-offs

\begin{tabular}{llllll}
\hline Cut-off & Sensitivity & Specificity & $\begin{array}{l}\text { Area under } \\
\text { the curve }\end{array}$ & $\begin{array}{l}\text { Positive } \\
\text { predictive value }\end{array}$ & $\begin{array}{l}\text { Negative } \\
\text { predictive value }\end{array}$ \\
\hline $15 \mathrm{~mm}$ & 2.8 & 99.7 & 0.51 & 10.9 & 0.97 \\
$20 \mathrm{~mm}$ & 6.2 & 99.5 & 0.53 & 11.5 & 0.94 \\
$25 \mathrm{~mm}$ & 10.6 & 97.3 & 0.54 & 3.9 & 0.91 \\
$30 \mathrm{~mm}$ & 30.7 & 80.1 & 0.55 & 1.5 & 0.86 \\
\hline
\end{tabular}

$66.5 \%$ (2979) at 21 weeks, and 20.5\% (917) at 22 weeks. The mean TUCL was of $33.8 \mathrm{~mm} \pm 4.8 \mathrm{~mm}$ (range: $3.0 \mathrm{~mm}$ to $53.0 \mathrm{~mm}$ ). Percentiles 3,5 and 10 corresponded to TUCLs of $25.0 \mathrm{~mm}, 27.0 \mathrm{~mm}$ and $29.0 \mathrm{~mm}$ respectively. -Table 2 presents the frequency of term and preterm births across different TUCL intervals. Among pregnant women with PTB, the TUCL was significantly lower (mean: $31.6 \mathrm{~mm}$; $95 \% \mathrm{CI}$ : $30.7-32.5 \mathrm{~mm}$ ) compared to the measurements of those with term birth (mean: $33.9 \mathrm{~mm}$; 95\%CI: 33.8-34.0 mm; $p<0.001$ ).

Even though the TUCL alone showed a high specificity to predict PTB, its diagnostic ability was limited by a very low sensitivity, with an AUC close to 0.5 for all different cut-offs studied, as depicted in table 3.

The univariate analysis (-Tables 4 and $\mathbf{5}$ ) showed that maternal age $\geq 40$ years, history of PTB, and cervical surgery were the main significant predictors of PTB. Additionally, history of PTB and previous cervical surgery were also associated with shorter TUCL, thus acting as confounders.

The multivariate logistic regression analysis, incorporating maternal age $\geq 40$ years old, history of PTB, and previous cervical surgery, evaluated the impact of the TUCL as a predictor of PTB (- Table 6 ).

The estimated odds ratio (OR) for the effect of the TUCL on PTB, controlling for covariates, was of 0.92 (95\%CI: 0.90-0.95; $p<0.001$ ), which highlights the significant negative association between TUCL and PTB. The diagnostic ability of the multivariate model improved, showing an AUC of 0.65 (-Fig. 2).

As expected, in the univariate analysis, the treatment with progesterone/pessary was associated with shorter TUCL, and thus, also with PTB, when considering the total study cohort.
Within the group of women with a diagnosis of short cervix, $68 \%(n=93)$ underwent treatment, and 13\% $(n=18)$ declined it. There was, however, no significant difference between the frequency of PTB among women who accepted or declined progesterone or the pessary (14\% versus $22.2 \%$ of PTB respectively; $p=0.472$ ); therefore, the treatment was not included in our multivariate model.

To select the optimal TUCL cut-off, we ran several multivariate logistic regression models using different cut-offs (from $8 \mathrm{~mm}$ and $50 \mathrm{~mm}$ ) associated with other variables like maternal age $\geq 40$ years, history of PTB, and previous cervical surgery. Plotting the log likelihood from these models against the TUCL showed that a cut-off of $20 \mathrm{~mm}$ (95\%CI: 19.5-$22 \mathrm{~mm}$ ) best discriminated 2 TUCL subgroups with differential odds for PTB (-Fig. 3). Women with a short cervix, defined by TUCL $\leq 20 \mathrm{~mm}$, had an OR of 12.2 (95\%Cl: 5.8-25.4; $p<0.001) \quad$ compared with those with TUCL $>20 \mathrm{~mm}$.

Considering maternal age $\geq 40$ years, history of PTB and previous cervical surgery as the main risk factors for PTB, a stratified analysis was performed by separately evaluating women with at least 1 of these factors $(n=297)$ versus women who did not presented any of them $(n=4,184$ [93.4\%]) (-Table 7). The significant association of a short cervix (TUCL $\leq 20 \mathrm{~mm}$ ) with PTB was maintained in both groups, with an OR of 16.2 (95\%CI: 2.7-97.1; $p<0.001$ ) for women with risk factors, and an OR of 9.8 (95\%CI: 4.1-23.7; $p<0.001$ ) for women without them. There was no effect modification between the groups $(p=0.614$, homogeneity test). Considering this stratification, the adjusted OR for women with short cervix (TUCL $\leq 20 \mathrm{~mm}$ ) was of 11.4 (95\%CI: 5.1-25.4; $p<0.001$ ). 
Table 4 Demographics comparing preterm and term births

\begin{tabular}{|c|c|c|c|c|}
\hline & & $\begin{array}{l}\text { Preterm birth - } \\
\mathrm{n}: 179(4.0 \%)\end{array}$ & $\begin{array}{l}\text { Term birth - } \\
\text { n: } 4302(96.0 \%)\end{array}$ & $p$-value \\
\hline \multirow[t]{3}{*}{ Maternal age } & Mean \pm standard deviation & $31.4 \pm 6.0$ & $30.7 \pm 5.5$ & $0.098^{\mathrm{a}}$ \\
\hline & $<40$ years old & $161(89.9 \%)$ & $4122(95.8 \%)$ & $<0.001^{\mathrm{b}}$ \\
\hline & $\geq 40$ years old & $18(10.1 \%)$ & $180(4.2 \%)$ & \\
\hline Body mass index & Mean $\left(\mathrm{kg} / \mathrm{m}^{2}\right)$ & $2397 \pm 5.3$ & $24.6 \pm 4.9$ & $0.055^{\mathrm{a}}$ \\
\hline \multirow[t]{2}{*}{ Schooling } & $\leq 12$ th grade & $111(62.4 \%)$ & $2807(65.4 \%)$ & $0.404^{b}$ \\
\hline & $>12$ th grade & 67 (37.6\%) & 1485 (34.6\%) & \\
\hline \multirow[t]{3}{*}{ Addictions } & Smoking & $21(11.7 \%)$ & $556(12.9 \%)$ & $0.640^{c}$ \\
\hline & Drugs & $0(0 \%)$ & $4(0.1 \%)$ & $1.000^{c}$ \\
\hline & Alcohol & $1(0.6 \%)$ & $4(0.1 \%)$ & $0.184^{\mathrm{c}}$ \\
\hline $\begin{array}{l}\text { Gestational age at } \\
\text { cervical length } \\
\text { measurement }\end{array}$ & Mean \pm standard deviation (weeks) & $21.5 \pm 0.5$ & $21.5 \pm 0.6$ & $0.592^{a}$ \\
\hline \multirow[t]{2}{*}{ Type of pregnancy } & Spontaneous & $165(95.4 \%)$ & $4,041(97.2 \%)$ & $0.150^{b}$ \\
\hline & Medical assisted & $8(4.6 \%)$ & $115(2.8 \%)$ & \\
\hline Gravidity & Primigravida & $83(46.5 \%)$ & $1,953(45.4 \%)$ & $0.789^{b}$ \\
\hline Parity & Nulliparous & $101(56.4 \%)$ & $2,417(56.2 \%)$ & $0.949^{b}$ \\
\hline \multirow[t]{3}{*}{ Obstetric history } & Preterm birth & $17(9.5 \%)$ & $55(1.3 \%)$ & $<0.001^{c}$ \\
\hline & Second trimester miscarriage & $1(0.6 \%)$ & $4(0.1 \%)$ & $0.184^{c}$ \\
\hline & Recurrent pregnancy loss & $2(1.1 \%)$ & $16(0.4 \%)$ & $0.160^{c}$ \\
\hline \multirow[t]{5}{*}{ Maternal background } & Conization & $10(5.6 \%)$ & $31(0.7 \%)$ & $<0.001^{\mathrm{b}}$ \\
\hline & Mullerian anomalies & $3(1.7 \%)$ & $11(0.3 \%)$ & $0.016^{c}$ \\
\hline & Chronic hypertension & $9(5.0 \%)$ & $100(2.3 \%)$ & $0.021^{\mathrm{b}}$ \\
\hline & Diabetes & $3(1.7 \%)$ & $28(0.7 \%)$ & $0.125^{\mathrm{c}}$ \\
\hline & Hypothyroidism & $7(3.9 \%)$ & $227(5.2 \%)$ & $0.429^{b}$ \\
\hline \multirow[t]{8}{*}{ Obstetrical complications } & Malformations and cromossomopathies & $6(3.4 \%)$ & $64(1.5 \%)$ & $0.059^{c}$ \\
\hline & Fetal growth restriction & $9(5.0 \%)$ & $167(3.9 \%)$ & $0.439^{b}$ \\
\hline & Hypertensive syndromes & 0 & $143(3.3 \%)$ & $0.040^{c}$ \\
\hline & Gestational diabetes & $24(1.4 \%)$ & 405 (9.4\%) & $0.751^{b}$ \\
\hline & Short interpregnancy intervals & $1(0.6 \%)$ & $4(0.1 \%)$ & $0.184^{\mathrm{c}}$ \\
\hline & Surgical procedure during pregnancy & $0(0 \%)$ & $7(0.2 \%)$ & $1.000^{c}$ \\
\hline & Urinary infections or asymptomatic bacteriuria & $8(4.5 \%)$ & $135(3.1 \%)$ & $0.321^{\mathrm{b}}$ \\
\hline & Others infections during pregnancy & $10(5.9 \%)$ & $188(4.4 \%)$ & $0.438^{\mathrm{b}}$ \\
\hline \multicolumn{2}{|c|}{$\begin{array}{l}\text { Treatment with progesterone } \\
\text { or Arabin pessary }\end{array}$} & 25 (13.9\%) & $116(2.7 \%)$ & $0.000^{\mathrm{b}}$ \\
\hline
\end{tabular}

Notes: ${ }^{\mathrm{a}}$-test; ${ }^{\mathrm{b}}$ Chi-squared test; ${ }^{\mathrm{c}}$ Fisher test.

A simple comparison of the $20-\mathrm{mm}$ and $25-\mathrm{mm}$ cut-offs, based on AUCs of multivariate models, showed no statistical difference $(20 \mathrm{~mm}$ : $\mathrm{AUC}=0.59$ [95\%CI: 0.56-0.62] versus $25 \mathrm{~mm}: \mathrm{AUC}=0.60$ [95\%CI: 0.57-0.64]; $p=0.157$ ). However, a better performance in the prediction of PTB of the 20$\mathrm{mm}$ compared to the $25-\mathrm{mm}$ cut-off was highlighted by comparing the distribution of women according to the prediction probabilities derived from the corresponding multivariate models. Globally, 15 (0.33\%) women were reclassified to a different predicted-probability group when the multivariate model included the $20-\mathrm{mm}$ instead of the 25-mm cut-off. As described in table 6, out of the 4 women upgraded to a higher probability (from 0.50-0.75 in the $25-\mathrm{mm}$ model to $>0.75$ in the $20-\mathrm{mm}$ model), $75 \%$ $(\mathrm{n}=3)$ experienced a PTB. On the other hand, out of the 8 women reclassified to a lower predicted probability (from $0.25-0.50$ in the $25-\mathrm{mm}$ model to $<0.25$ in the $20-\mathrm{mm}$ model), only 1 (12.5\%) had PTB. 
270 The Impact of Routine Transvaginal Ultrasound Measurement de Almeida et al.

Table 5 Cervical length description according to demographics

\begin{tabular}{|c|c|c|c|c|}
\hline & & & $\begin{array}{l}\text { Cervical length } \\
\text { (mean } \pm \text { standard } \\
\text { deviation) }\end{array}$ & $p$-value ${ }^{a}$ \\
\hline \multirow[t]{2}{*}{ Maternal age } & $<40$ years old & & $33.8 \pm 4.8$ & 0.546 \\
\hline & $\geq 40$ years old & & $34.0 \pm 5.0$ & \\
\hline \multirow[t]{2}{*}{ Schooling } & $\leq 12$ th grade & & $33.8 \pm 4.8$ & 0.568 \\
\hline & $>12$ th grade & & $33.9 \pm 4.9$ & \\
\hline \multirow[t]{6}{*}{ Addictions } & Smoking & No & $33.9 \pm 4.8$ & 0.089 \\
\hline & & Yes & $33.5 \pm 5.3$ & \\
\hline & Drugs & No & $33.8 \pm 4.8$ & 0.443 \\
\hline & & Yes & $35.5 \pm 2.8$ & \\
\hline & Alcohol & No & $33.8 \pm 4.8$ & 0.170 \\
\hline & & Yes & $30.5 \pm 3.1$ & \\
\hline \multirow[t]{2}{*}{ Type of pregnancy } & Spontaneous & & $33.8 \pm 4.8$ & 0.664 \\
\hline & Medically-assisted & & $33.6 \pm 6.4$ & \\
\hline \multirow[t]{2}{*}{ Gravidity } & Primigravida & & $33.5 \pm 4.8$ & 0.000 \\
\hline & Multigravida & & $34.1 \pm 4.9$ & \\
\hline \multirow[t]{2}{*}{ Parity } & Nulliparous & & $33.4 \pm 4.8$ & 0.000 \\
\hline & Multiparous & & $34.3 \pm 4.8$ & \\
\hline \multirow[t]{6}{*}{ Obstetric history } & Preterm birth & No & $33.9 \pm 4.8$ & 0.000 \\
\hline & & Yes & $31.8 \pm 5.0$ & \\
\hline & Second-trimester miscarriage & No & $33.8 \pm 4.8$ & 0.001 \\
\hline & & Yes & $26.8 \pm 8.4$ & \\
\hline & Recurrent pregnancy loss & No & $33.8 \pm 4.8$ & 0.412 \\
\hline & & Yes & $32.3 \pm 7.9$ & \\
\hline \multirow[t]{10}{*}{ Maternal background } & Conization & No & $33.9 \pm 4.8$ & 0.000 \\
\hline & & Yes & $30.8 \pm 5.6$ & \\
\hline & Mullerian anomalies & No & $33.8 \pm 4.8$ & 0.993 \\
\hline & & Yes & $33.9 \pm 3.2$ & \\
\hline & Chronic hypertension & No & $33.8 \pm 4.8$ & 0.540 \\
\hline & & Yes & $34.1 \pm 6.2$ & \\
\hline & Diabetes & No & $33.8 \pm 4.8$ & 0.120 \\
\hline & & Yes & $35.9 \pm 4.6$ & \\
\hline & Hypothyroidism & No & $33.8 \pm 4.9$ & 0.659 \\
\hline & & Yes & $34.0 \pm 4.5$ & \\
\hline \multirow[t]{16}{*}{ Obstetrical complications } & Malformations and cromossomopathies & No & $33.8 \pm 4.8$ & 0.821 \\
\hline & & Yes & $34.0 \pm 4.9$ & \\
\hline & Fetal growth restriction & No & $33.9 \pm 4.8$ & 0.000 \\
\hline & & Yes & $32.4 \pm 4.9$ & \\
\hline & Hypertensive syndromes & No & $33.8 \pm 4.8$ & 0.448 \\
\hline & & Yes & $33.5 \pm 4.8$ & \\
\hline & Gestational diabetes & No & $33.8 \pm 4.8$ & 0.967 \\
\hline & & Yes & $33.8 \pm 45.0$ & \\
\hline & Short interpregnancy intervals & No & $33.8 \pm 4.8$ & 0.871 \\
\hline & & Yes & $34.3 \pm 2.4$ & \\
\hline & Surgical procedure during pregnancy & No & $33.8 \pm 4.8$ & 0.934 \\
\hline & & Yes & $34.0 \pm 3.3$ & \\
\hline & Urinary infections or asymptomatic bacteriuria & No & $33.8 \pm 4.8$ & 0,112 \\
\hline & & Yes & $33.12 \pm 4.8$ & \\
\hline & Other infections during pregnancy & No & $33.9 \pm 4.9$ & 0.880 \\
\hline & & Yes & $33.2 \pm 4.6$ & \\
\hline \multirow{2}{*}{$\begin{array}{l}\text { Treatment with progesterone } \\
\text { or Arabin pessary }\end{array}$} & & No & $34.2 \pm 4.3$ & 0.000 \\
\hline & & Yes & $24.1 \pm 7.2$ & \\
\hline
\end{tabular}

Note: ${ }^{\mathrm{a}}$-test. 
Table 6 Multivariate logistic regression analysis to evaluate the impact of transvaginal ultrasound measurement of the cervical length as a predictor of preterm birth

\begin{tabular}{lllll}
\hline Outcome & Odds ratio & $\begin{array}{l}\text { 95\% confi- } \\
\text { dence } \\
\text { interval }\end{array}$ & p-value \\
\hline Cervical length & 0.925 & 0.90 & 0.95 & 0.000 \\
Maternal age & 2.265 & 1.32 & 3.90 & 0.003 \\
Previous preterm birth & 6.754 & 3.72 & 12.16 & 0.000 \\
Cervical surgery & 0.178 & 0.81 & 0.40 & 0.000 \\
Constant & 14.557 & 2.61 & 81.31 & 0.002 \\
\hline
\end{tabular}

Fig. 3 Plotting to determine the best TUCL cut-off based on multiple log likelihood of the logistic regression model (including maternal age $\geq 40$ years, history of PTB, and previous cervical surgery), using cutoffs between $8 \mathrm{~mm}$ and $50 \mathrm{~mm}$. The circle represents the cut-off that best discriminated the risk of experiencing PTB.

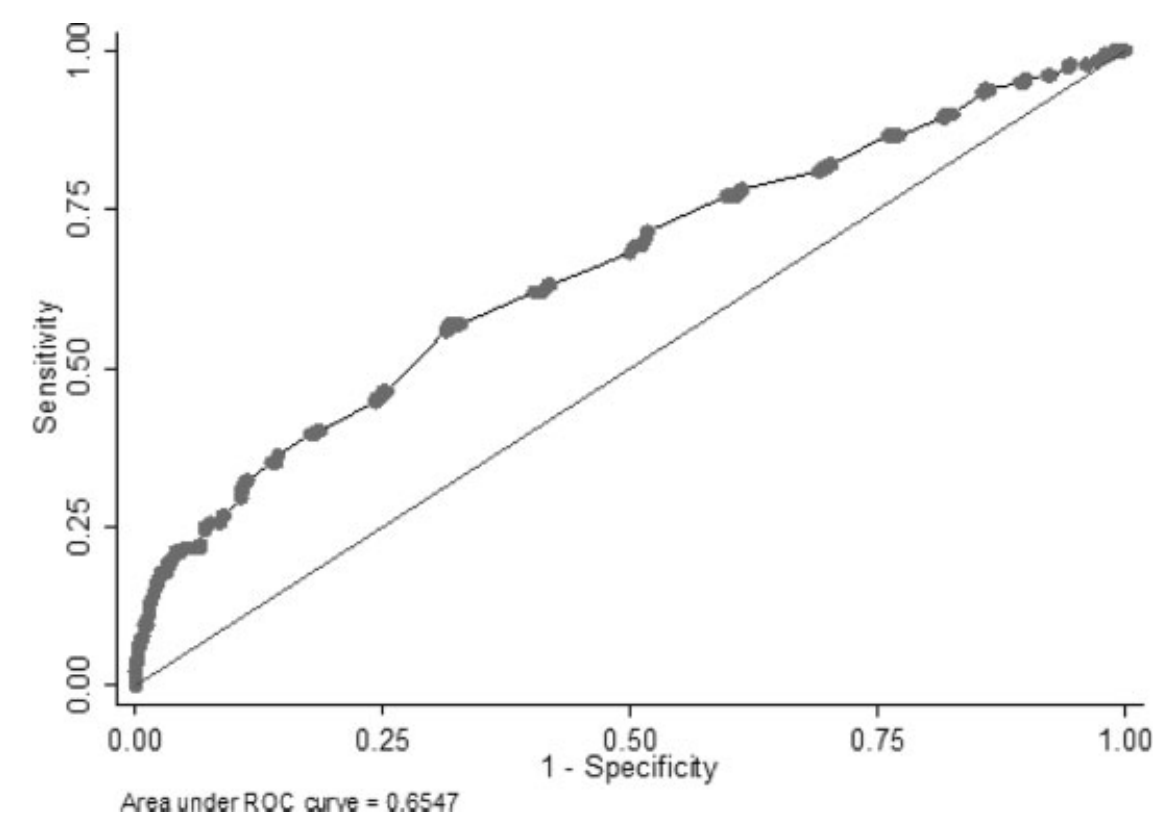

Fig. 2 Graphic representations of sensitivity, specificity and area under the curve (AUC) of the multivariate model.

Table 7 Distribution of the pregnant women according to group probability of preterm birth using transvaginal ultrasound measurement of the cervical length and presence/absence of risk factors (maternal age $\geq 40$ years, previous PTB and cervical surgery). Cross-classification of the 25 -mm cut-off group (most used cut-off) versus the 20-mm cut-off group (our best cut-off) and frequency of PTB in each subgroup

\begin{tabular}{|c|c|c|c|c|c|c|}
\hline & & \multicolumn{5}{|c|}{ Group probability - TUCL: $20 \mathrm{~mm}$} \\
\hline & & $<0.25$ & $0.25-0.50$ & $0.50-0.75$ & $\geq 0.75$ & Total reclassified \\
\hline \multirow{8}{*}{$\begin{array}{l}\text { Group probability } \\
\text { - TUCL: } 25 \mathrm{~mm}\end{array}$} & $<0.25$ & 4,456 & 1 & 0 & 0 & $0.02 \%$ \\
\hline & PTB\% (n) & $3.8 \%(168)$ & $0 \%$ & $0 \%$ & $0 \%$ & \\
\hline & $0.25-0.50$ & 8 & 8 & 2 & 0 & $55.6 \%$ \\
\hline & PTB\% (n) & $12.5 \%(1)$ & $50.0 \%(4)$ & $50.0 \%(1)$ & $0 \%$ & \\
\hline & $0.50-0.75$ & 0 & 0 & 1 & 4 & $80.0 \%$ \\
\hline & PTB\% (n) & $0 \%$ & $0 \%$ & $100 \%(1)$ & $75.0 \%(n 3)$ & \\
\hline & $\geq 0.75$ & 0 & 0 & 0 & 1 & $0 \%$ \\
\hline & PTB\% (n) & $0 \%$ & $0 \%$ & $0 \%$ & $0 \%$ & \\
\hline
\end{tabular}

Abbreviations: PTB, preterm birth; TUCL, transvaginal ultrasound measurement of the cervical length. 


\section{Discussion}

Good practice of disease screening recommends that the condition be an important health problem and facilities for diagnosis and treatment be available, as already published in 1968 by the WHO. ${ }^{28}$

Preterm birth fulfills the first prerequisite, as it represents a major obstetric complication. Our cohort presents 4\% (179) of spontaneous PTB, and this prevalence is similar to that of other studies regarding screening and treatment. ${ }^{27,29,30}$

A second assumption needed to implement a screening process is the existence of a test able to detect the high-risk population, and the TUCL satisfies this requirement. An inverse association between the TUCL and PTB, which was also observed in our study, has been widely documented. ${ }^{16,21,26,27,29-32}$ The TUCL in our cohort showed a high specificity to predict PTB, but low sensitivity and a poor AUC, results similar to those of other studies. Iams et al. ${ }^{27}$ reported that TUCL $\leq 25 \mathrm{~mm}$ had a sensitivity of $37 \%$ and a specificity of $92 \%$, but more recent studies obtained even lower sensitivities, such as $2.4 \%$ in the study by van der Ven et al., ${ }^{33}$ and $8.0 \%$ in the one by Esplin et al. ${ }^{34}$

Our multivariate model showed an improvement in the AUC value, highlighting that a combined screening including maternal age $>40$ years, history of PTB and previous cervical surgery should be considered for screening, instead of the TUCL alone. The Society for Maternal-Fetal Medicine Publications Committee, in their 2012 guidelines, concluded that the most effective approach was to initiate treatment in lowrisk women with a TUCL $\leq 20 \mathrm{~mm}$, or high-risk pregnant women with a TUCL $\leq 25 \mathrm{~mm}$, supporting that other risk factors should be included in the screening algorithm. ${ }^{35}$

Nowadays, there is no debate that second-trimester TUCL is the most powerful screening instrument available, but the best cut-off to separate normal from short cervixes is still controversial. ${ }^{16,19-23}$ As most parameters in medicine, there is no biological TUCL cut-off, and defining "short" is not an easy task. Lower cut-offs present good specificity but low sensitivity, but higher values (like $29 \mathrm{~mm}$ ) lead to an increase in the false-positive rate. ${ }^{27,36}$ Most guidelines recommend a 25-mm cut-off, as it corresponds to the 10th percentile in the initial published trials. ${ }^{7,15,16,27,36-40}$ However, more recent studies showed a lower prevalence of short cervices defined as TUCL $\leq 25 \mathrm{~mm}$, averaging $2.5 \% .^{14,33,34,41,42}$ Our results follow this new tendency, as the prevalence of TUCL $\leq 25 \mathrm{~mm}$ was of only $3 \%$ (134), and the 10th TUCL percentile in our cohort corresponded to $29.0 \mathrm{~mm}$.

TUCL distribution can be influenced by many factors; therefore, the ideal cut-off can change in different populations. That said, we concluded that the best cut-off for our cohort was $20 \mathrm{~mm}$ (-Fig. 3). This value enabled us to improve the prediction of the risk of experiencing PTB mainly by reducing the false-positive rate $(8$ women were reclassified as low probability, and only 1 (15.5\%) of them experienced a PTB).

In parallel to studies on the efficacy of TUCL screening, cost-analysis studies were also conducted, which concluded that TUCL screening is cost-effective even if we assume a low incidence of short cervical length and a modest impact of the treatment with progesterone. ${ }^{25,31,43-45}$

The Federation of Gynecology and Obstetrics Working Group on Best Practices in Maternal Fetal Medicine recommended universal transvaginal cervical length screening and vaginal progesterone when $\mathrm{TUCL}<25 \mathrm{~mm}$. ${ }^{46}$ Subsequently, studies ${ }^{41,42,47}$ using this recommendation showed a reduction in the PTB rate when universal screening was applied. Son et al., ${ }^{42}$ for example, obtained a $20 \%$ reduction in the rate of PTBs after implementing TUCL screening, even with a very low prevalence short cervixes (TUCL $\leq 25 \mathrm{~mm}$ : $0.89 \%$ ). The negative impact of PTB is so huge that every approach able to reduce it has a positive impact and should be considered.

\section{Conclusion}

Preterm birth represents a major health problem, and strategies to prevent are important. The present study showed an inverse association between TUCL and PTB, and emphasized that other factors like maternal age, history PTB and previous cervical surgery can improve the screening algorithm. The value that defines a short cervix can differ in each population, and, for our cohort, the best cutoff was $20 \mathrm{~mm}$. Even though TUCL has a low diagnostic performance, it is the best screening method available to predict $\mathrm{PTB}$, and TUCL screening has been shown to reduce the PTB rate.

\section{Contributors}

All authors were involved in the design and interpretation of the analyses, contributed to the writing of the manuscript, and read and approved the final manuscript.

\section{Conflict of Interests}

The authors have no conflict of interests to declare.

\section{References}

1 Glover AV, Manuck TA. Screening for spontaneous preterm birth and resultant therapies to reduce neonatal morbidity and mortality: A review. Semin Fetal Neonatal Med. 2018;23(02): 126-132. Doi: 10.1016/j.siny.2017.11.007

2 Purisch SE, Gyamfi-Bannerman C. Epidemiology of preterm birth. Semin Perinatol. 2017;41(07):387-391. Doi: 10.1053/j.semperi.2017.07.009

3 Vogel JP, Chawanpaiboon S, Moller AB, Watananirun K, Bonet M, Lumbiganon P. The global epidemiology of preterm birth. Best Pract Res Clin Obstet Gynaecol. 2018;52:3-12. Doi: 10.1016/j. bpobgyn.2018.04.003

4 Zeitlin J, Szamotulska K, Drewniak N, et al; Euro-Peristat Preterm Study Group. Preterm birth time trends in Europe: a study of 19 countries. BJOG. 2013;120(11):1356-1365. Doi: 10.1111/14710528.12281

5 Frey HA, Klebanoff MA. The epidemiology, etiology, and costs of preterm birth. Semin Fetal Neonatal Med. 2016;21(02):68-73. Doi: 10.1016/j.siny.2015.12.011

6 Liu L, Oza S, Hogan D, et al. Global, regional, and national causes of under-5 mortality in 2000-15: an updated systematic analysis with implications for the Sustainable Development Goals. Lancet. 2016;388(10063):3027-3035. Doi: 10.1016/S0140-6736(16) 31593-8 
7 Committee on Practice Bulletins-Obstetrics, The American College of Obstetricians and Gynecologists. Practice bulletin no. 130: prediction and prevention of preterm birth. Obstet Gynecol. 2012;120(04):964-973. Doi: 10.1097/AOG.0b013e3182723b1b

8 Dodd JM, Jones L, Flenady V, Cincotta R, Crowther CA. Prenatal administration of progesterone for preventing preterm birth in women considered to be at risk of preterm birth. Cochrane Database Syst Rev. 2013;(07):CD004947. Doi: 10.1002/14651858.CD004947

9 Howson CP, Kinney MV, McDougall L, Lawn JEBorn Too Soon Preterm Birth Action Group. Born too soon: preterm birth matters. Reprod Health. 2013;10(Suppl 1):S1. Doi: 10.1186/17424755-10-S1-S1

10 Yoshida S, Martines J, Lawn JE, et al; neonatal health research priority setting group. Setting research priorities to improve global newborn health and prevent stillbirths by 2025. J Glob Health. 2016;6(01):010508. Doi: 10.7189/jogh.06.010508

11 Loureiro T, Cunha M, Montenegro N. [Sonographic measurement of cervical length and prediction of spontaneous preterm delivery: how useful is it?] Acta Med Port. 2006;19(05):395-404 Portuguese

12 Barde DMPS, Attal DMP. Transvaginal sonographic cervical length measurement as predictor of preterm delivery. Int J Med Sci Clin Invent. 2017;4(07):3129-3132. Doi: 10.18535/ ijmsci/v4i7.17

13 Krupa FG, Faltin D, Cecatti JG, Surita FGC, Souza JP. Predictors of preterm birth. Int J Gynaecol Obstet. 2006;94(01):5-11. Doi: 10.1016/j.ijgo.2006.03.022

14 Temming LA, Durst JK, Tuuli MG, et al. Universal cervical length screening: implementation and outcomes. Am J Obstet Gynecol. 2016;214(04):523.e1-523.e8. Doi: 10.1016/j.ajog.2016.02.002

15 McIntosh J, Feltovich H, Berghella V, Manuck TSociety for Maternal-Fetal Medicine (SMFM). Electronic address: pubs@smfm.org. The role of routine cervical length screening in selected high- and low-risk women for preterm birth prevention. Am J Obstet Gynecol. 2016;215(03):B2-B7. Doi: 10.1016/j.ajog.2016.04.027

16 Andersen HF, Nugent CE, Wanty SD, Hayashi RH. Prediction of risk for preterm delivery by ultrasonographic measurement of cervical length. Am J Obstet Gynecol. 1990;163(03):859-867. Doi: 10.1016/0002-9378(90)91084-p

17 Leung TN, Pang MW, Leung TY, Poon CF, Wong SM, Lau TK. Cervical length at 18-22 weeks of gestation for prediction of spontaneous preterm delivery in Hong Kong Chinese women. Ultrasound Obstet Gynecol. 2005;26(07):713-717. Doi: 10.1002/ uog.2617

18 Burger M, Weber-Rössler T, Willmann M. Measurement of the pregnant cervix by transvaginal sonography: an interobserver study and new standards to improve the interobserver variability. Ultrasound Obstet Gynecol. 1997;9(03):188-193. Doi: 10.1046/ j.1469-0705.1997.09030188.x

19 van Os MA, Kleinrouweler CE, Schuit E, et al. Influence of cut-off value on prevalence of short cervical length. Ultrasound Obstet Gynecol. 2017;49(03):330-336. Doi: 10.1002/uog.15967

20 Wulff CB, Rode L, Rosthøj S, Hoseth E, Petersen OB, Tabor A. Transvaginal sonographic cervical length in first and second trimesters in a low-risk population: a prospective study. Ultrasound Obstet Gynecol. 2018;51(05):604-613. Doi: 10.1002/ uog.17556

21 Markham KB, Iams JD. Measuring the cervical length. Clin Obstet Gynecol. 2016;59(02):252-263. Doi: 10.1097/ GRF.0000000000000204

22 Verma S, Meena BS, Pooja P, Sehra RN. A study of cervical length measured ultrasonographically in prediction of preterm delivery. J Obstet Gynaecol. 2017;3(04):38-43

23 Orzechowski KM, Nicholas SS, Baxter JK, Weiner S, Berghella V. Implementation of a universal cervical length screening program for the prevention of preterm birth. Am J Perinatol. 2014;31(12): 1057-1062. Doi: 10.1055/s-0034-1371710
24 Berghella V, Baxter JK, Hendrix NW. Cervical assessment by ultrasound for preventing preterm delivery. Obstet Gynecol. 2009;114 (05):1140-1141. Doi: 10.1097/AOG.0b013e3181bdca73

25 Jain S, Kilgore M, Edwards RK, Owen J. Revisiting the costeffectiveness of universal cervical length screening: importance of progesterone efficacy. Am J Obstet Gynecol. 2016;215(01):101. e1-101.e7. Doi: 10.1016/j.ajog.2016.01.165

26 Barros-Silva J, Pedrosa AC, Matias A. Sonographic measurement of cervical length as a predictor of preterm delivery: a systematic review. J Perinat Med. 2014;42(03):281-293. Doi: 10.1515/jpm2013-0115

27 Iams JD, Goldenberg RL, Meis PJ, et al; National Institute of Child Health and Human Development Maternal Fetal Medicine Unit Network. The length of the cervix and the risk of spontaneous premature delivery. N Engl J Med. 1996;334(09):567-572. Doi: 10.1056/NEJM199602293340904

28 Wilson JMG, Jungner G. Principles and practice of screening for disease. Geneva: World Health Organization; 1968

29 Kuusela P, Jacobsson B, Söderlund M, et al. Transvaginal sonographic evaluation of cervical length in the second trimester of asymptomatic singleton pregnancies, and the risk of preterm delivery. Acta Obstet Gynecol Scand. 2015;94(06):598-607. Doi: $10.1111 /$ aogs.12622

30 Souka AP, Papastefanou I, Pilalis A, Kassanos D, Papadopoulos G. Implementation of universal screening for preterm delivery by mid-trimester cervical-length measurement. Ultrasound Obstet Gynecol. 2019;53(03):396-401. Doi: 10.1002/uog.19050

31 Pedretti MK, Kazemier BM, Dickinson JE, Mol BW. Implementing universal cervical length screening in asymptomatic women with singleton pregnancies: challenges and opportunities. Aust N Z J Obstet Gynaecol. 2017;57(02):221-227. Doi: 10.1111/ajo.12586

32 Conde-Agudelo A, Romero R. Vaginal progesterone to prevent preterm birth in pregnant women with a sonographic short cervix: clinical and public health implications. Am J Obstet Gynecol. 2016;214(02):235-242. Doi: 10.1016/j. ajog.2015.09.102

33 van der Ven J, van Os MA, Kazemier BM, et al. The capacity of midpregnancy cervical length to predict preterm birth in low-risk women: a national cohort study. Acta Obstet Gynecol Scand. 2015;94(11):1223-1234. Doi: 10.1111/aogs.12721

34 Esplin MS, Elovitz MA, Iams JD, et al; nuMoM2b Network. Predictive accuracy of serial transvaginal cervical lengths and quantitative vaginal fetal fibronectin levels for spontaneous preterm birth among nulliparous women. JAMA. 2017;317(10): 1047-1056. Doi: 10.1001/jama.2017.1373

35 Society for Maternal-Fetal Medicine Publications Committee, with assistance of Vincenzo Berghella. Progesterone and preterm birth prevention: translating clinical trials data into clinical practice. Am J Obstet Gynecol. 2012;206(05):376-386. Doi: 10.1016/j.ajog.2012.03.010

36 Taipale P, Hiilesmaa V. Sonographic measurement of uterine cervix at 18-22 weeks' gestation and the risk of preterm delivery. Obstet Gynecol. 1998;92(06):902-907. Doi: 10.1016/s0029-7844 (98)00346-9

37 Hassan SS, Romero R, Berry SM, et al. Patients with an ultrasonographic cervical length $<$ or $=15 \mathrm{~mm}$ have nearly a $50 \%$ risk of early spontaneous preterm delivery. Am J Obstet Gynecol. 2000; 182(06):1458-1467. Doi: 10.1067/mob.2000.106851

38 Romero R, Conde-Agudelo A, Da Fonseca E, et al. Vaginal progesterone for preventing preterm birth and adverse perinatal outcomes in singleton gestations with a short cervix: a meta-analysis of individual patient data. Am J Obstet Gynecol. 2018;218(02): 161-180. Doi: 10.1016/j.ajog.2017.11.576

39 Fonseca EB, Celik E, Parra M, Singh M, Nicolaides KHFetal Medicine Foundation Second Trimester Screening Group. Progesterone and the risk of preterm birth among women with a short cervix. $\mathrm{N}$ Engl J Med. 2007;357(05):462-469. Doi: 10.1056/NEJMoa067815 
40 Berghella V, Palacio M, Ness A, Alfirevic Z, Nicolaides KH, Saccone $G$. Cervical length screening for prevention of preterm birth in singleton pregnancy with threatened preterm labor: systematic review and meta-analysis of randomized controlled trials using individual patient-level data. Ultrasound Obstet Gynecol. 2017;49 (03):322-329. Doi: 10.1002/uog.17388

41 Orzechowski KM, Boelig RC, Baxter JK, Berghella V. A universal transvaginal cervical length screening program for preterm birth prevention. Obstet Gynecol. 2014;124(03):520-525. Doi: 10.1097/AOG.0000000000000428

42 Son M, Grobman WA, Ayala NK, Miller ES. A universal midtrimester transvaginal cervical length screening program and its associated reduced preterm birth rate. Am J Obstet Gynecol. 2016;214(03):365.e1-365.e5. Doi: 10.1016/j.ajog.2015.12.020

43 Crosby DA, Miletin J, Semberova J, Daly S. Is routine transvaginal cervical length measurement cost-effective in a population where the risk of spontaneous preterm birth is low? Acta Obstet Gynecol Scand. 2016;95(12):1391-1395. Doi: 10.1111/aogs.13021
44 Einerson BD, Grobman WA, Miller ES. Cost-effectiveness of riskbased screening for cervical length to prevent preterm birth. Am J Obstet Gynecol. 2016;215(01):100.e1-100.e7. Doi: 10.1016/j. ajog.2016.01.192

45 Werner EF, Hamel MS, Orzechowski K, Berghella V, Thung SF. Costeffectiveness of transvaginal ultrasound cervical length screening in singletons without a prior preterm birth: an update. Am J Obstet Gynecol. 2015;213(04):554.e1-554.e6. Doi: 10.1016/j. ajog.2015.06.020

46 Figo Working Group On Best Practice In Maternal-Fetal Medicine International Federation of Gynecology and Obstetrics. Best practice in maternal-fetal medicine. Int J Gynaecol Obstet. 2015;128 (01):80-82. Doi: 10.1016/j.ijgo.2014.10.011

47 Newnham JP, White SW, Meharry S, et al. Reducing preterm birth by a statewide multifaceted program: an implementation study. Am J Obstet Gynecol. 2017;216(05):434-442. Doi: 10.1016/j. ajog.2016.11.1037 